\title{
Permeabilitas dan Pergerakan Pejalan Kaki terhadap Physical Distancing (Studi Kasus: Jalan Malioboro)
}

\author{
Fasiha Putri Untsa ${ }^{1}$, Dyah Widi Astuti ${ }^{2}$ \\ 1,2 Program Studi Arsitektur, Universitas Muhammadiyah Surakarta, Indonesia. +62271717417 \\ Email Korespondensi: fasihaputri@gmail.com
}

\section{INFORMASI ARTIKEL}

Abstract: The existence of public spaces, especially pedestrian ways during the pandemic, has become a high priority in urban planning. The current study aims to examine the impact of spatial configuration and pedestrian movements of Malioboro Street on the effectiveness of physical distancing. The use of space syntax to determine the quality of spatial configuration through the permeability level and observation by counting and tracking to interpret the pedestrian movements. The result shows the need to add more space for pedestrian because there is correlation between the permeability and increased pedestrian movement can hinder the implementation of physical distancing. Good management of street space can be the solution in meeting the need

Keywords: Permeability; Pedestrian; Physical Distancing; Malioboro Street; Space Syntax

\begin{abstract}
Abstrak: Eksistensi ruang publik terutama jalur pedestrian saat pandemi menjadi prioritas utama dalam perencanaan kota. Penelitian ini bertujuan untuk memahami dampak konfigurasi spasial dan pergerakan pejalan kaki pada ruang jalan terhadap efektivitas physical distancing. Penggunaan metode space syntax dalam menentukan kualitas konfigurasi spasial Jalan Malioboro melalui tingkat permeabilitas dan metode observasi melalui counting dan tracing dalam memahami pergerakan pejalan kaki. Hasil penelitian menunjukan perlunya penambahan ruang yang lebih bagi pejalan kaki, karena adanya korelasi antara permeabilitas dengan peningkatan pergerakan pejalan kaki yang dapat menghambat implementasi physical distancing. Pengelolaan ruang jalan yang baik dapat menjadi solusi dalam memenuhi kebutuhan tersebut
\end{abstract}

Kata Kunci: Permeabilitas; Pejalan Kaki; Physical Distancing; Jalan Malioboro; Space Syntax

Article history:

Received; 2021-05-11

Revised; 2021-08-27

Accepted; 2021-09-24

\section{PENDAHULUAN}

WHO atau World Health Organization secara resmi menetapkan COVID-19 sebagai wabah pandemi, dikarenakan lebih dari 50 negara telah mengalami penyebaran coronavirus (Ducharme, 2020). Penerapan aturan physical distancing menjadi salah satu langkah kebijakan paling efektif dalam mencegah penyebaran virus di ruang publik selama pandemi (WilderSmith \& Freedman, 2020). Namun, pada kenyataannya physical distancing sulit diterapkan di ruang publik (Nazmy, 2020). Penelitian terhadap ruang publik diperlukan guna menyiapkan strategi dalam mencegah penyebaran virus era pandemi (Alter, 2020; Florida, 2020; Null \& Smith, 2020). Strategi diperlukan guna mengetahui kapasitas ruang publik dalam menampung kebutuhan berinteraksi sosial sekaligus menerapkan aturan physical distancing (UN-Habitat, 2020). Ruang jalan merupakan bagian dari ruang publik perkotaan yang menjamin kualitas hidup penggunanya (Litscher, 2020). Ruang jalan berperan penting sebagai zona utama dalam melindungi kesehatan masyarakat saat pandemi sekaligus menyediakan kebutuhan dasar, baik kebutuhan fisik dan mental (NACTO, 2020).

Jalan Malioboro merupakan jalan penunjang kehidupan dalam aspek sosial, ekonomi, dan budaya (Mahadi \& Budiarti, 2016). Hal tersebut menyebabkan kawasan Jalan Malioboro menjadi area yang diperhatikan saat krisis pandemi. Jalan Malioboro sebagai ruang publik yang merupakan elemen arsitektur perkotaan, seharusnya memiliki peluang dalam menerjemahkan 
aturan physical distancing menjadi praktik spasial dalam mencegah penyebaran virus (Carmona, 2019). Pernyataan tersebut diperkuat berdasarkan studi yang dilakukan oleh peneliti dari TU Delft di Belanda, yang menyebutkan bahwa pedestrian dengan lebar lebih dari 3,5 meter memiliki peluang dalam menerapkan physical distancing dengan mudah (Psyllidis, et al., 2020). Namun, hal tersebut berbanding terbalik dengan realita yang terjadi di Jalan Malioboro. Tercatatat sejak dibukanya kembali Malioboro pada bulan Mei 2020, terjadi peningkatan pengunjung yang berdampak pada adanya pedagang PKL terpapar virus (Anugrahanto, 2020). Dapat disimpulkan bahwa intervensi yang dilakukan pemerintah dalam mencegah penyebaran virus belum efektif.

Tulisan ini berupaya untuk membahas bagaimana kondisi Jalan Malioboro era pandemi, apabila dilihat dari tingkat permeabilitas dan pergerakan pejalan kaki pada kawasan tersebut serta rekomendasi strategi seperti apa yang diperlukan untuk memaksimalkan implementasi aturan physical distancing di Jalan Malioboro. Bertolak dari permasalahan tersebut, penelitian ini bertujuan untuk melakukan studi terhadap pergerakan pejalan kaki dan memahami bagaimana dampak kualitas permeabilitas pada struktur ruang jalan yang ada terhadap implementasi physical distancing di Jalan Malioboro serta memberikan atau menyediakan informasi berupa strategi dalam merespon pandemi di Jalan Malioboro.

\section{Permeabilitas}

Studi yang dilakukan oleh (Cristani, et al., 2020), menjelaskan penggunaan proxemics theory dalam menguji kepatuhan sesorang terhadap aturan physical distancing tergantung pada pengaturan konfigurasi spasial dan jumlah orang yang terlibat. Studi tersebut menyoroti pentingnya kualitas spasial dan ruang disekitar seseorang berdasarkan jarak interpersonal. Hal tersebut sesuai dengan konsep permeabilitas pada suatu ruang (Abdul Nasir, et al., 2020). Permeabilitas menggambarkan sejauh mana orang diizinkan atau dibatasi untuk bergerak di suatu tempat, baik dengan berjalan kaki atau dengan menaiki kendaraan. Secara teoritis, hal ini dapat dievaluasi melalui space syntax dalam menentukan tingkat permeabilitas. Bentley (1985) dalam (Mensana, et al., 2019), menyebutkan bahwa kualitas permeabilitas berfungsi sebagai parameter untuk mengukur sejauh mana konfigurasi ruang dalam menyediakan pilihan (rute) dalam menempuh perjalanan dan aksesibilitas. Dalam kaitannya dengan pandemi, pengukuran terhadap kualitas permeabilitas ruang jalan diperlukan guna mengetahui dampak konfigurasi spasial terhadap implementasi physical distancing. Dalam hal ini, variabel yang digunakan dalam melihat tingkat permeabilitas dalam suatu kawasan meliputi: analisis konektivitas, analisis integrasi, analisis choice (potensi keterpilihan rute berjalan), jaringan ruang pejalan kaki (pedestrian way), dan struktur kawasan (Aqli, 2019).

\section{Pejalan Kaki}

Menurut Kusbianto (2007) dalam (Marlina, 2020), pejalan kaki atau pedestrian adalah salah satu unsur pengguna jalan. Pedestrian juga dapat didefinisikan sebagai sirkulasi atau pergerakan orang dari satu tempat ke titik asal (origin) dan ketempat lain sebagai tujuan (destination) dengan berjalan kaki (Rubenstein, 1978). Jalur yang diperuntukkan bagi pejalan kaki dan kaum penyandang cacat disebut dengan jalur pejalan kaki (pedestrian sidewalk). Shirvani (1985) dalam (Mauliani, et al., 2013), mengatakan bahwa jalur pejalan kaki sebagai ruang publik menjamin terpenuhinya kebutuhan fisik dan psikologis pemakainya. Kaitannya dengan pandemi, setiap ruang publik membutuhkan strategi untuk mengidentifikasi taktik yang digunakan dalam melakukan intervensi saat pandemi. Strategi tersebut diperoleh berdasarkan pemahaman tentang pergerakan pejalan kaki yang berfokus pada cara orang bernavigasi dan menghabiskan waktu di ruang publik era pandemi (Gehl \& Svarre, 2013). Pendekatan ini diperlukan untuk mengidentifikasi apa yang berhasil dan apa yang tidak dalam merancang rekomendasi strategi atau desain yang peka terhadap perilaku manusia. 


\section{Physical Distancing dan COVID-19}

Munculnya COVID-19 menandakan adanya pandemi dan gaya hidup new normal, yang dapat mempengaruhi pertimbangan dalam perencanaan desain yang baik bagi kesehatan masyarakat (Shiue, 2016). Komite Penanganan COVID-19 mendefinisikan physical distancing sebagai menjaga jarak lebih dari 1 meter dengan siapapun, dengan kata lain tidak berdekatan dan tidak berkumpul (covid19.go.id, 2020). Physical distancing adalah salah satu alternatif dalam mengelola tata ruang di masa pandemi, yakni dengan menjaga jarak antar orang di ruang publik minimal 2 meter (Schwartz, 2020). Menurut (WHO, 2020), istilah physical distancing lebih baik digunakan daripada social distancing. Dikarenakan physical distancing mengacu pada menjaga diri dengan orang lain secara fisik dan tetap terhubung secara sosial, sedangkan social distancing lebih mengacu pada pembatasan interaksi sosial antar sesama (social isolation) (Gupta \& Dhamija, 2020). Penerapan aturan physical distancing merupakan metode yang efektif dalam membantu memperlambat penyebaran SARS-CoV-2, virus yang menyebabkan COVID-19 (Chu, et al., 2020).

\section{METODE PENELITIAN}

Metode penelitian yang digunakan adalah mixed method (kuantitatif dan kualitatif). Melakukan pengamatan langsung (observasi) dan penerapan space syntax untuk menghasilkan interpretasi hubungan permeabilitas dan pergerakan pedestrian yang ada di Jalan Malioboro. Penggabungan metode observasi dan space syntax mengacu pada rekomendasi studi ruang publik yang dilakukan oleh Kristin Westlund dalam laporan tesisnya yang berjudul Methods for Studying Public Space's Impact on Their Life (2018). Kedua metode ini memiliki perbedaan dalam pendekatannya, space syntax menggunakan pendekatan dari perspektif ruang dan observasi menggunakan perspektif dari pengguna ruang jalan. Penggabungan keduanya dimanfaatkan untuk mendapatkan pemahaman yang lebih dalam guna mencapai hasil penelitian yang sesuai dengan rumusan masalah (Westlund, 2018).

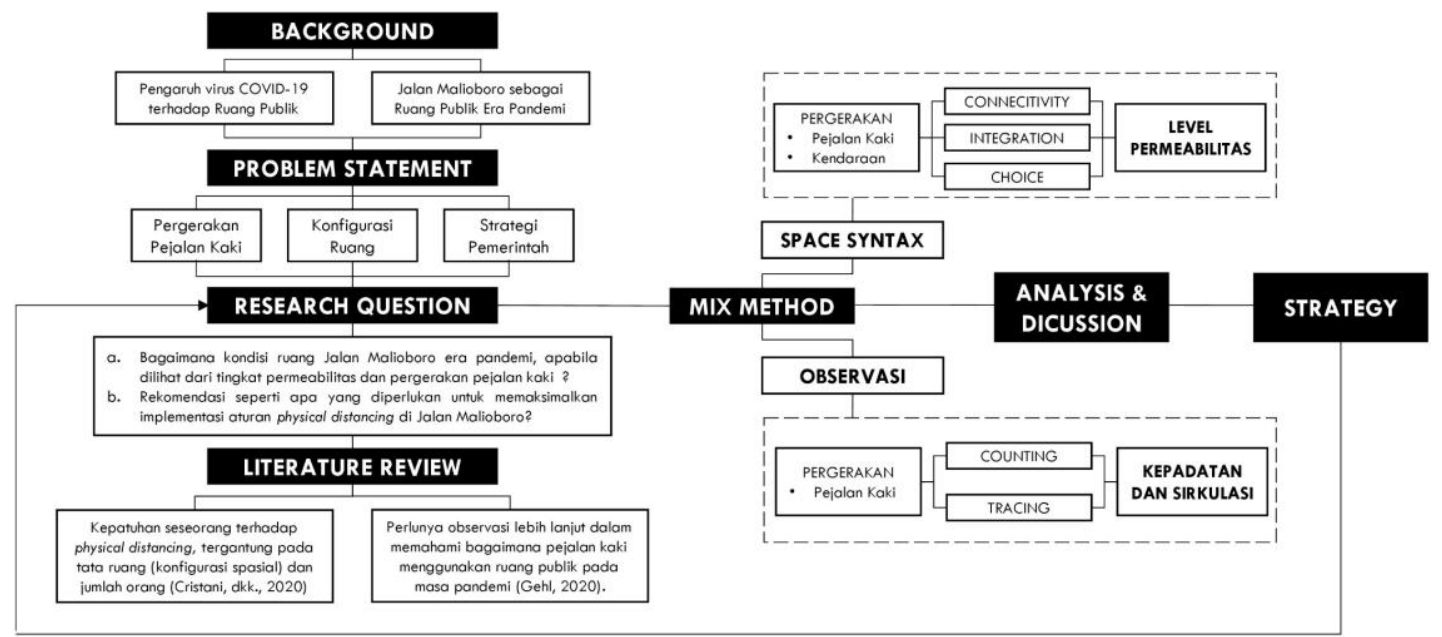

Gambar 1. Kerangka berpikir (mind map) pada penelitian

Lokasi penelitian adalah Jalan Malioboro yang teridiri dari kawasan jalur pedestrian yang membentang dari persimpangan jalan yang dilewati rel kereta api hingga persimpangan jalan pada Titik Nol Kilometer Yogyakarta. Area studi jalur pedestrian yang dimaksud adalah ruang jalan yang terdiri dari: Jalan Malioboro, Jalan Margo Mulyo, Jalan Jenderal Ahmad Yani, dan cabang jalan yang bersinggungan dengan ketiga jalan tersebut. 


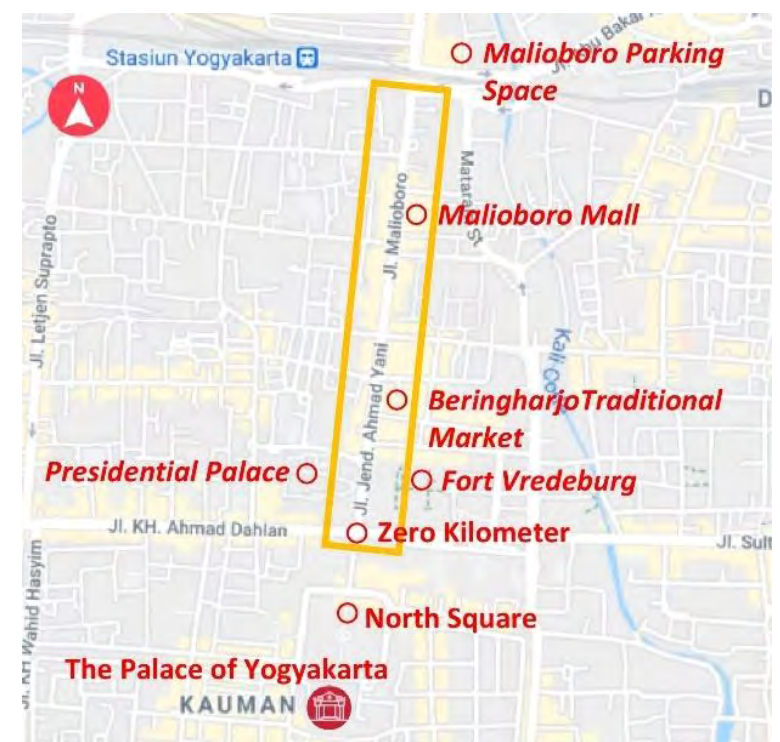

\section{Gambar 2. Lokasi penelitian adalah jalur pedestrian Malioboro}

\section{Teknik Pengumpulan Data Space Syntax}

Space syntax merupakan sebuah metode untuk menganalisa hubungan yang terbentuk antara ruang terbuka dan struktur ruang yang ada (Hillier \& Hanson, 1984). Space syntax sebagai program spatial network dalam menghasilkan korelasi antara manusia dengan struktur pembentuk ruang di dalam teori perancangan kota dan arsitektural. Program ini dimanfaatkan untuk analisis studi melalui rutinitas pergerakan, pemaknaan ruang, dan konfigurasi ruang. Oleh karena itu, penggunaan teori space syntax sesuai dengan tujuan dari penelitian, yaitu memahami level permeabilitas sebuah struktur ruang jalan (Vujadinovic, 2016). Penerapan dilakukan dengan mengumpulkan data eksisting berupa struktur ruang Jalan Malioboro dan dianalisis menggunakan software Depthmap X-0.8.0.

Metode axial space yang menghasilkan axial analysis digunakan dalam penelitian ini dengan mencakup tiga variabel yang menentukan kualitas permeabilitas dari struktur Jalan Malioboro. Ketiga variabel tersebut adalah:

a. Konektivitas (connectivity), dimensi ukuran nilai sebuah ruang yang terhubung langsung dengan ruang lainnya. Potensi konektivitas tinggi dimiliki oleh ruang yang paling banyak terhubung dengan ruang lainnya.

b. Integrasi (integration), dimensi nilai keterkaitan sebuah ruang dengan ruang yang lain, baik secara langsung maupun tidak langsung. Integrasi memprediksi seberapa besar tingkat pertemuan yang terjadi dalam ruang.

c. Keterpelihan (choice), terkait seberapa potensi rute (pilihan) yang akan diambil oleh pergerakan pejalan kaki terhadap struktur ruang.

Hasil ketiga variabel tersebut menghasilkan perbedaan kedalaman berupa tampilan spektrum warna biru hingga merah (Gambar 3). Warna biru merupakan area paling sedikit berhubungan dengan ruang jalan yang lain dan paling sedikit menerima pergerakan. Warna merah merupakan area dengan pergerakan terbanyak dan area yang paling banyak berhubungan dengan ruang jalan lain. 


\begin{tabular}{|l|l|}
\hline \multicolumn{2}{|l}{ RENTANG NILAI WARNA } \\
\hline Biru Tua & $0 \%-10 \%$ \\
\hline Biru & $10 \%-20 \%$ \\
\hline Biru Muda & $20 \%-30 \%$ \\
\hline Biru Kehijauan & $30 \%-40 \%$ \\
\hline Hijau Kebiruan & $40 \%-50 \%$ \\
\hline Hijau & $50 \%-60 \%$ \\
Hijau Kekuningan & $60 \%-70 \%$ \\
Kuning & $70 \%-80 \%$ \\
\hline Jingga & $80 \%-90 \%$ \\
\hline Merah & $90 \%-100 \%$ \\
\hline
\end{tabular}

Gambar 3. Rentang nilai warna space syntax Sumber: (Andi, et al., 2020)

\section{Observasi}

Metode observasi dilaksanakan untuk melengkapi analisis space syntax. Pelaksanaan metode ini berdasarkan teknik pengamatan Jan Gehl dan Birgitte Svarre pada bukunya How to Study Public Life (2013). Data diperoleh dengan mengamati rutinitas pergerakan pedestrian sehari-hari, melalui metode beikut ini (Oberklaid, 2015):

a. Metode perhitungan (counting), yaitu mengambil data dengan cara menghitung pedestrian yang melewati sebuah area jalan untuk mengambil sample kepadatan. Observasi dilaksanakan selama seminggu dengan membagi waktu dalam sehari menjadi empat bagian, yaitu: pagi hari (07.00 - 09.00), tengah hari $(11.00-13.00)$, sore hari (16.00 - 18.00), dan malam hari (19.00 - 21.00).

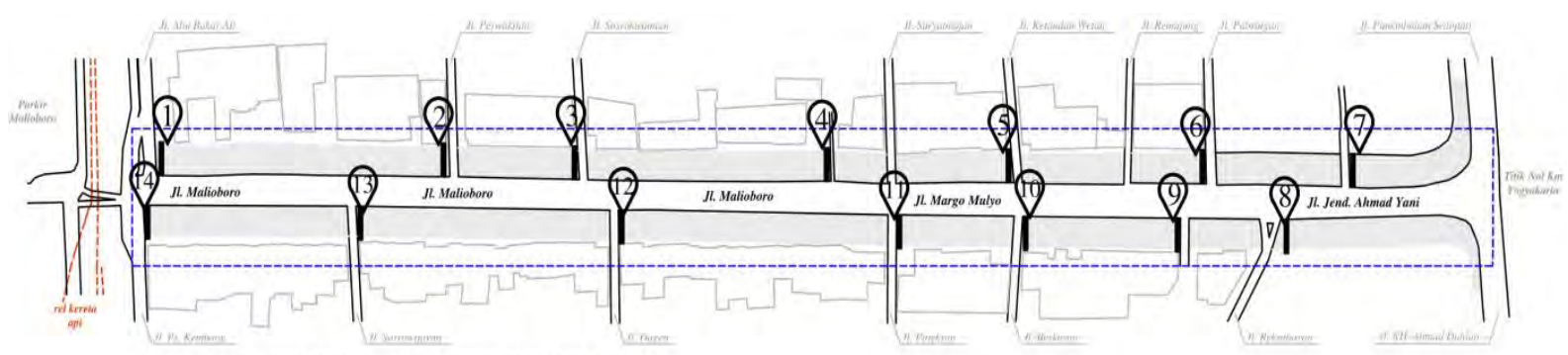

(JALAN MALIOBORO) - PEDESTRIAN COUNTING

Study area

Counting positions for pedestrian traffic

\section{Gambar 4. Titik lokasi pengamatan metode counting}

b. Metode penelusuran (tracing) dilakukan untuk memahami pergerakan orang dari satu titik ke titik yang lain. Metode penelusuran memberi gambaran yang jelas terhadap pergerakan orang di dalam ruang. Hasil pengamatan dapat digambarkan sebagai garis gerakan pada area yang dipelajari (Gehl \& Svarre, 2013). Observasi dilakukan selama 10 menit pada satu hari, yaitu 10 menit pada pagi hari, tengah hari, sore hari, dan malam hari. 


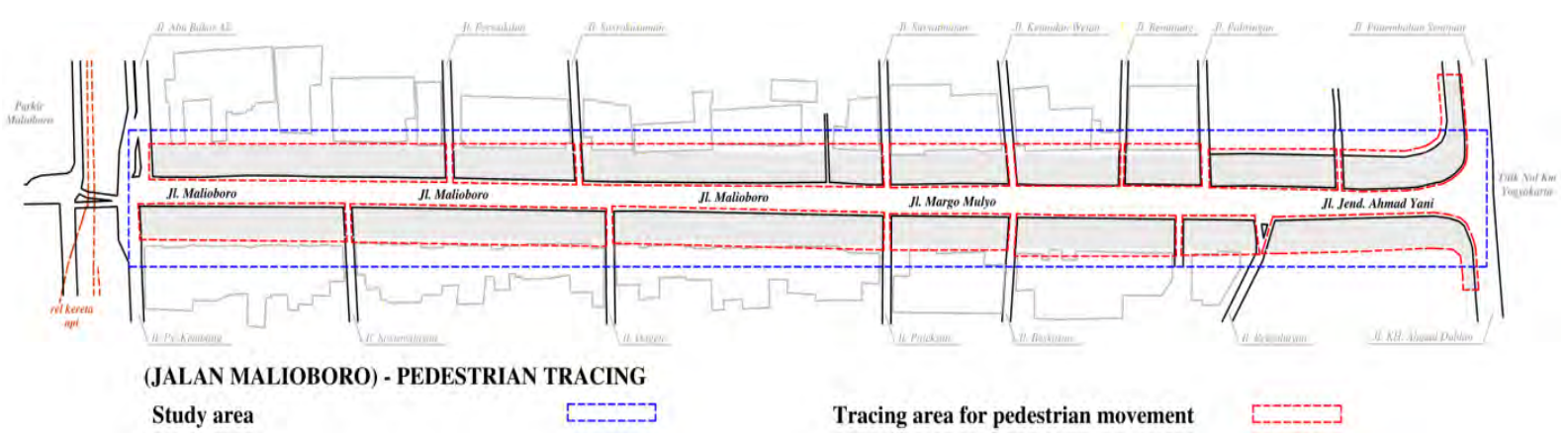

Gambar 5. Area lokasi pengamatan untuk metode tracing

\section{Analisis Permeabilitas}

Konfigurasi struktur ruang dapat dinilai dari pendekatan space syntax untuk mengetahui kuat lemahnya sebuah tatanan bentuk guna akan memudahkan dalam melihat level atau nilai permeabilitas suatu sistem.

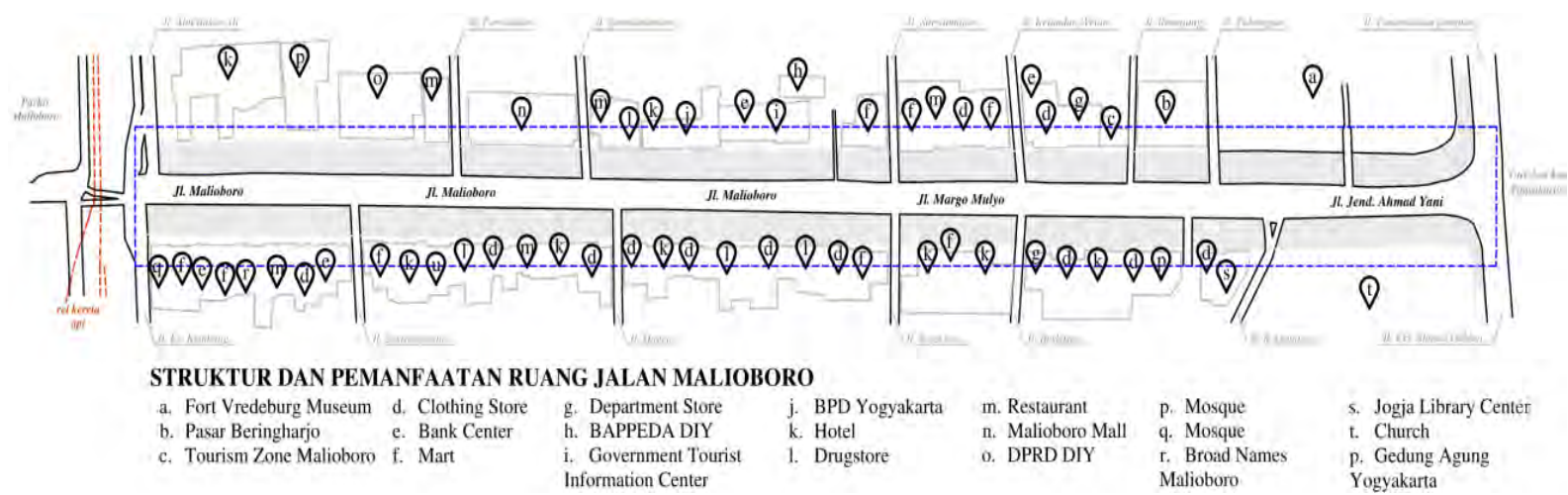

\section{Gambar 6. Struktur ruang Jalan Malioboro}

\section{Analisis Konektivitas (Connectivity)}

Pada Gambar 7 memperlihatkan hampir seluruh struktur jalan memiliki dominan visual warna merah-kuning (70\%-100\%), terutama pada ruang Jalan Malioboro-Jalan Margo Mulyo. Dari hal tersebut dapat disimpulkan bahwa struktur jalan memiliki potensi banyak di lalui orang skala kota. Potensi konektivitas tinggi disebabkan karena struktur Jalan Malioboro memiliki persinggungan ruang jalan yang baling banyak dibanding yang lain.

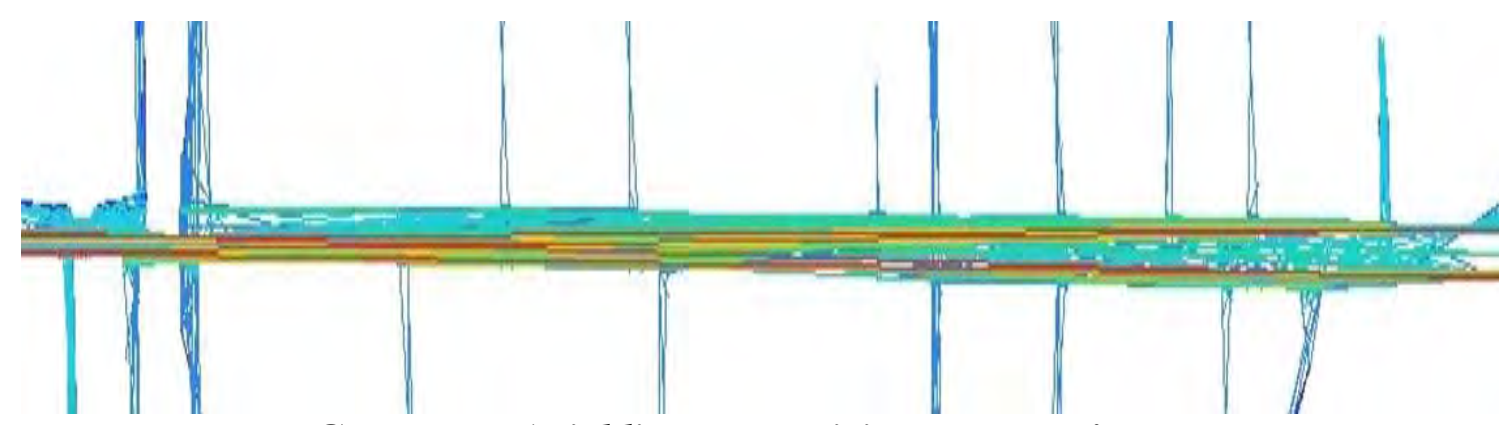

Gambar 7. Axial line connectivity Jalan Malioboro

\section{Analisis Integrasi (Integration)}

Pada hasil visual Gambar 8, terlihat bahwa struktur ruang Jalan Malioboro dominan berwarna merah-hijau kebiruan (40\%-100\%) sehingga nilai intregitas yang dimiliki berada pada nilai sedang dan tinggi. Nilai integrasi sedang-tinggi terjadi di Jalan Malioboro hingga Jalan Jenderal Ahmad Yani. Hal tersebut disebabkan karena struktur ruang memiliki jarak antar 
ruas jalan yang relatif pendek. Jadi, dapat dikatakan bahwa Jalan Malioboro terintegrasi kuat dengan kawasan lain yang menjadikan jalan tersebut sebagai inti kawasan yang mempunyai pengaruh besar terhadap ruang jalan di sekitarnya.

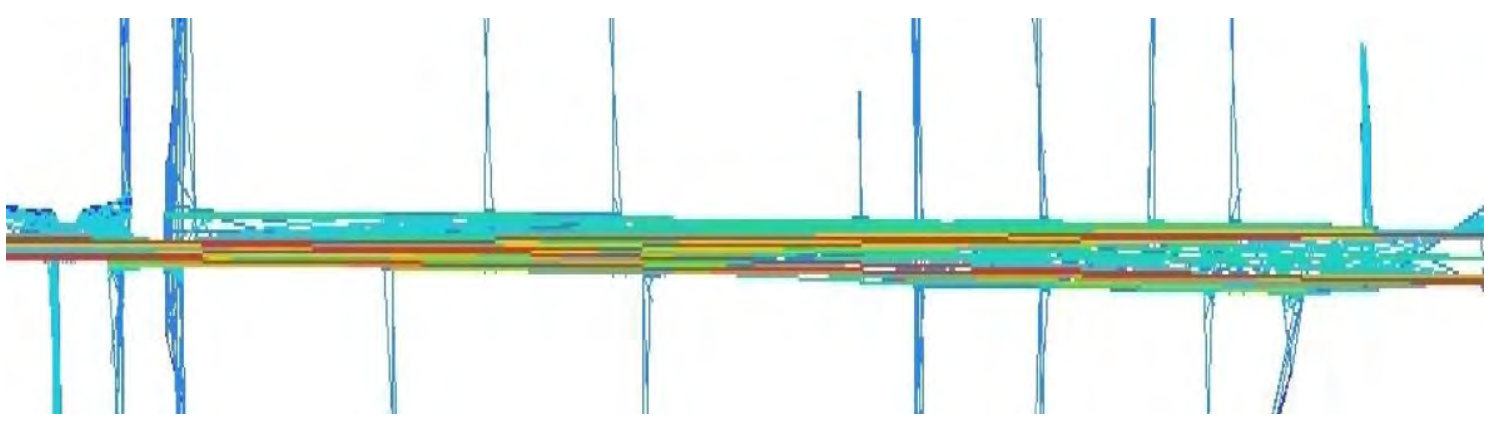

Gambar 8. Axial line integrity analysis Jalan Malioboro

\section{Analisis Keterpilihan (Choice)}

Analisis menunjukkan potensi keterpilihan terhadap rute berjalan kaki dengan memperlihatkan ukuran nilai pergerakan yang melalui sebuah ruang. Tingkat potensi keterpilihan berjalan kaki dengan besaran tertinggi (Gambar 9) ada pada area dominan warna kuning-hijau kebiruan (80\%-40\%), yaitu Jalan Malioboro hingga Jalan Margo Mulyo. Hal tersebut menjadikan jalur pedestrian Malioboro memiliki potensi pergerakan pejalan kaki dengan tingkat sedang-tinggi dibanding struktur jalan yang lain. Dapat disimpulkan bahwa pedestrian lebih sering menggunakan Jalan Malioboro dalam menempuh sebuah destinasi, sehingga memicu pergerakan masa yang cukup tinggi.

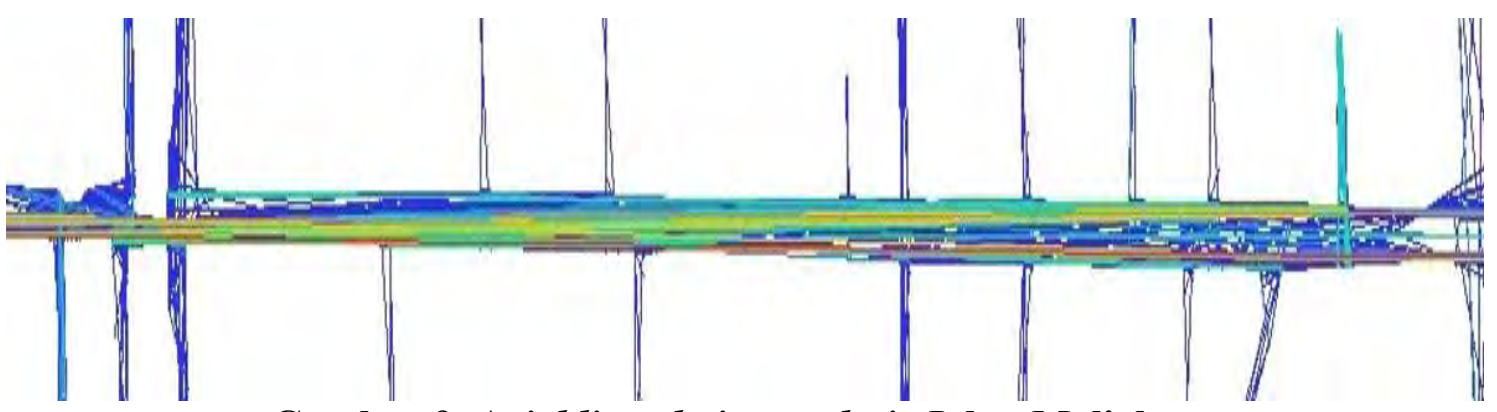

Gambar 9. Axial line choice analysis Jalan Malioboro

\section{Analisis Hasil Observasi Pejalan Kaki}

Analisa diperlukan untuk mengetahui lebih detail rutinitas pergerakan pejalan kaki, guna menambah wawasan terkait analisa space syntax. Data observasi diambil selama delapan hari, pada tanggal 3 Januari 2021 melakukan observasi metode tracing dan metode counting dilaksanakan pada tanggal 4 - 11 Januari 2021.

\section{Analisa Counting Pejalan Kaki}

Pada Gambar 10 menunjukkan area-area mana saja yang paling banyak dilalui pejalan kaki berdasarkan perbedaan waktu selama observasi. 


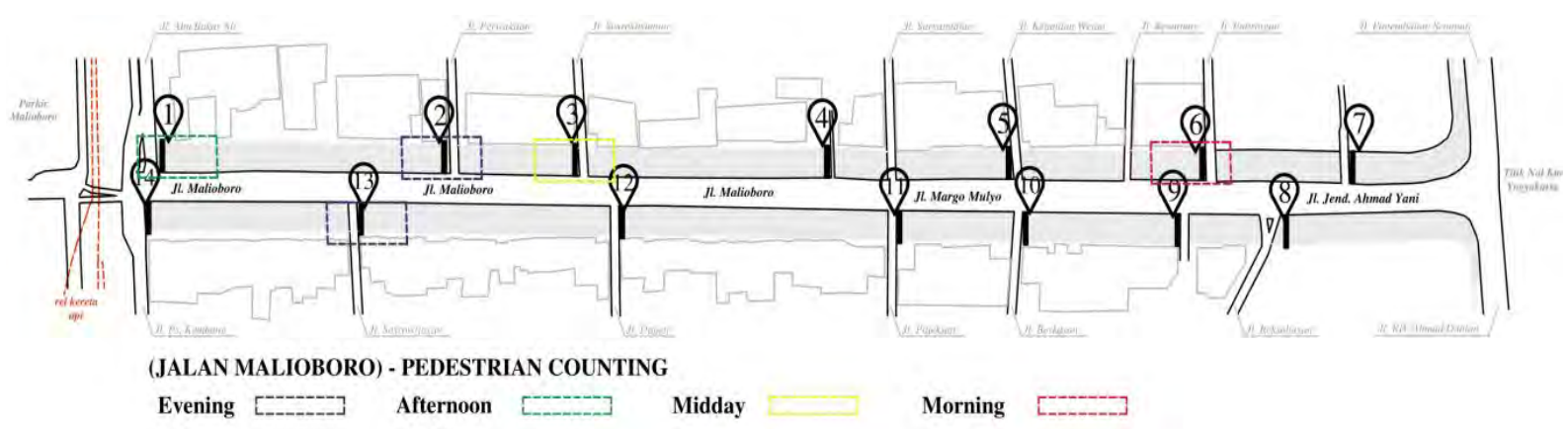

Gambar 10. Area pedestrian counting paling tinggi di Jalan Malioboro

Berdasarkan hasil pedestrian counting ditemukan beberapa area yang paling banyak dilalui pejalan kaki berdasarkan perbedaan waktu selama observasi, yaitu

- Area 6 (Pasar Beringharjo): pagi hari (morning) (5-7 ped/mnt)

- Area 3 (Malioboro Mall): tengah hari (midday) (6-8 ped/mnt)

- Area 1 (Entrance - Parkir Malioboro): sore hari (afternoon) (7-9 ped/mnt)

- Area 2 dan 13 (area komersial, Malioboro Mall): malam hari (evening) (9-11 ped/mnt)

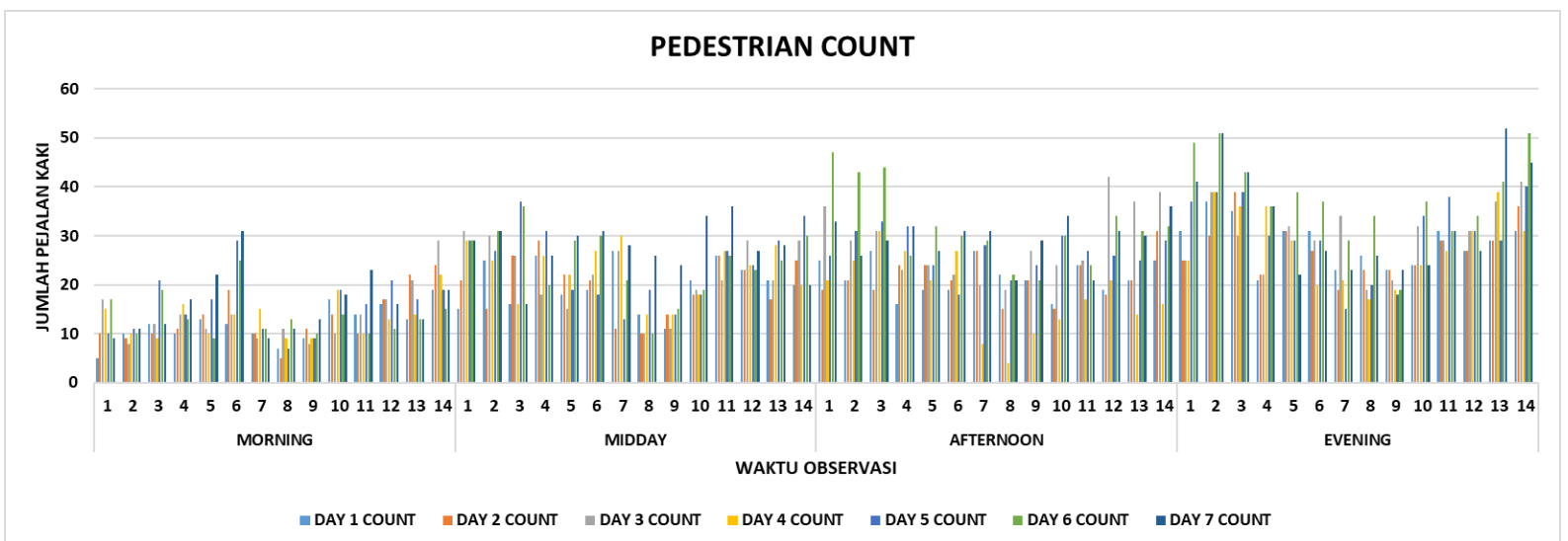

Gambar 11. Diagram hasil pedestrian counting Jalan Malioboro

Penggunaan lahan pada area 2 dan 13 berada di daerah Malioboro Mall yang dikelilingi area komersial di sekitarnya, yakni: kedai makanan, hotel, toko baju, toko serbaguna, dan toko obat. Berdasarkan hal tersebut, disimpulkan bahwa keberadaan Malioboro Mall di Jalan Malioboro memicu peningkatan pejalan kaki. Berdasarkan observasi ditemukan bahwa Jalan Malioboro mengalami peningkatan pengunjung dari pagi menuju malam hari (Gambar 11).

\section{Analisa Tracing Pejalan Kaki}

Hasil analisa tracing atau penelusuran pejalan kaki digunakan untuk mengetahui kemana saja pejalan kaki bergerak atau berpindah, sehingga dapat mengetahui sirkulasi yang sedang terjadi di ruang Jalan Malioboro. Berdasarkan hasil pemetaan observasi pada Gambar 12, menunjukkan bahwa sirkulasi pejalan kaki pada masa pandemi belum teratur. Sirkulasi atau pergerakan yang paling banyak terjadi terdapat pada bagian depan bangunan (frontage) dan jalur lalu lalang pejalan kaki atau jalur yang tidak terdapat street furniture seperti tempat duduk atau pohon. 


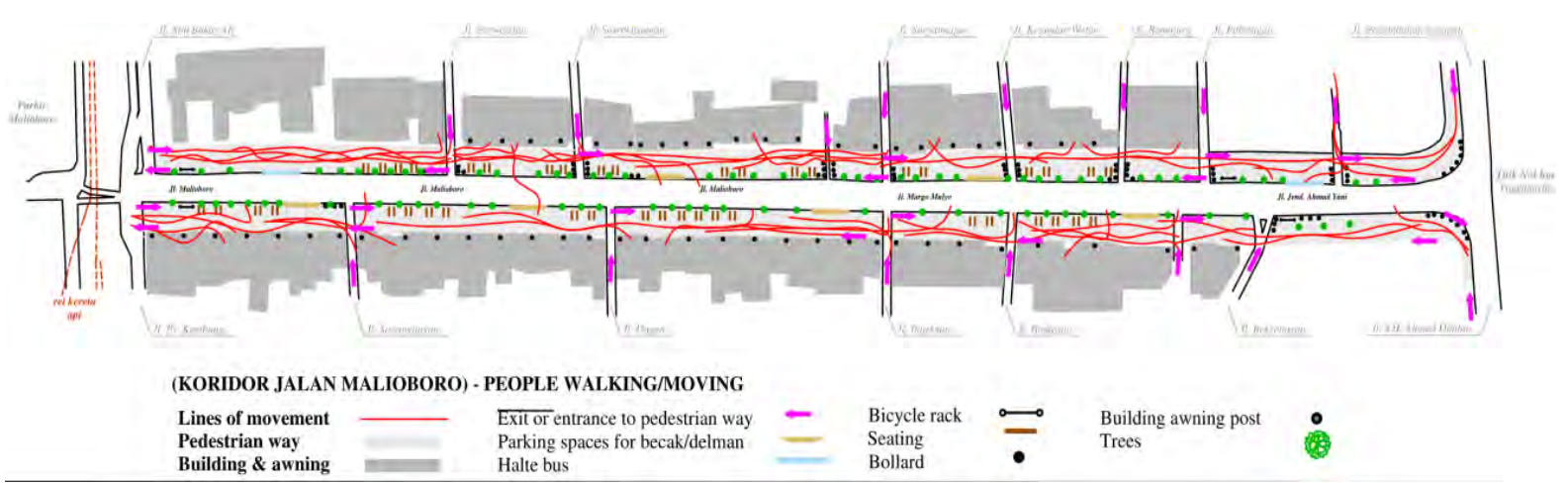

Gambar 12. Hasil penelusuran pedestrian Jalan Malioboro

\section{Kondisi Eksisting Ruang Jalan Malioboro \\ Permeabilitas}

PEMBAHASAN

Hasil analisis space syntax pada struktur ruang Jalan Malioboro menunjukkan tingkat konektivitas yang tinggi, dikarenakan konfigurasi ruangnya memiliki keterhubungan dengan banyak ruang jalan yang lain secara langsung. Adapun tingkat integrasi struktur ruang jalan yang dihasilkan adalah sedang hingga tinggi dikarenakan sruktur ruang jalannya terintegrasi dengan anak jalan yang lain dalam konfigurasi ruang, Tingkat keterpilihan rute berjalan kaki yang ditunjukkan oleh Jalan Malioboro adalah tingkat sedang hingga tinggi yang memicu pergerakan massa yang tingi melalui Jalan Malioboro.

Berdasarkan ketiga variabel tersebut, dapat disimpulkan bahwa struktur ruang jalan memiliki aksesibilitas yang tinggi sehingga memicu kepadatan yang relatif tinggi. Terutama pada Jalan Malioboro hingga Jalan Margo Mulyo, memiki ruang jalan yang mudah diakses bagi pejalan baik bergerak menggunakan kaki ataupun kendaraan. Hal tersebut menunjukkan bahwa susunan jalan linear yang memiliki cabang anak jalan yang banyak dapat meningkatkan pergerakan.

\section{Pergerakan Pejalan Kaki}

Hasil observasi menunjukkan bahwa terjadi peningkatan pedestrian dari pagi hari hingga malam hari. Area yang mengalami peningkatan tertinggi terjadi di area 2 dan 13 yang merupakan area berdekatan dengan Malioboro Mall yaitu pada malam hari pada akhir pekan. Terjadinya peningkatan jumlah pejalan kaki disertai dengan pangaturan arus perpindahan pejalan kaki yang tidak teratur. Sirkulasi pejalan kaki bervariasi karena tiap orang berpindah ke toko-toko dan fasilitas-fasilitas yang berbeda.

\section{Kaitannya dengan Implementasi Physical Distancing}

Tingkat permeabilitas atau aksesibilitas yang baik pada ruang Jalan Malioboro mengindikasikan bahwa tingkat pertemuan antar orang dalam berkegiatan yang terjadi di dalamnya berpotensi tinggi, baik itu dengan berjalan kaki ataupun menggunakan kendaraan. Hal tersebut menjadi pemicu peningkatan pergerakan pejalan kaki, sehingga dapat dikatakan bahwa karakteristik struktur ruang atau konfigurasi spasial Jalan Malioboro memengaruhi kepadatan masa menjadi tinggi. Korelasi antara permeabilitas dan pergerakan pejalan kaki menimbulkan banyak terjadinya persinggungan atau crossing antar kendaraan dan pejalan kaki (Gambar 13). 


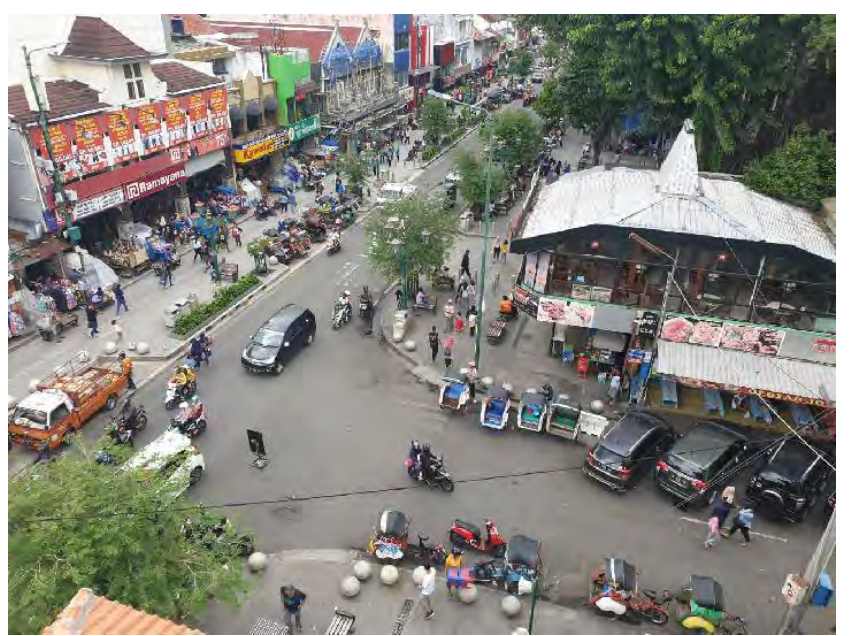

\section{Gambar 13. Suasana Jalan Malioboro ketika siang hari (titk amatan area 2)}

Crossing antar kendaraan dan pejalan kaki sering menimbulkan berkurangnya kapasitas ruang jalan yang digunakan untuk berjalan kaki. Kepadatan pedestrian memberikan dampak positif untuk keberlangsungan kegiatan ekonomi dan sosial pada Jalan Malioboro, yang merupakan ruang publik. Namun, selama era pandemi ini kepadatan masa menjadi hal yang harus dicegah untuk menekan penyebaran pandemi. Terlebih apabila sirkulasi pejalan kaki yang terjadi di Jalan Malioboro tidak diatur dengan baik terutama pada saat diiringi peningkatan pada jumlah kendaraan (Gambar 14).

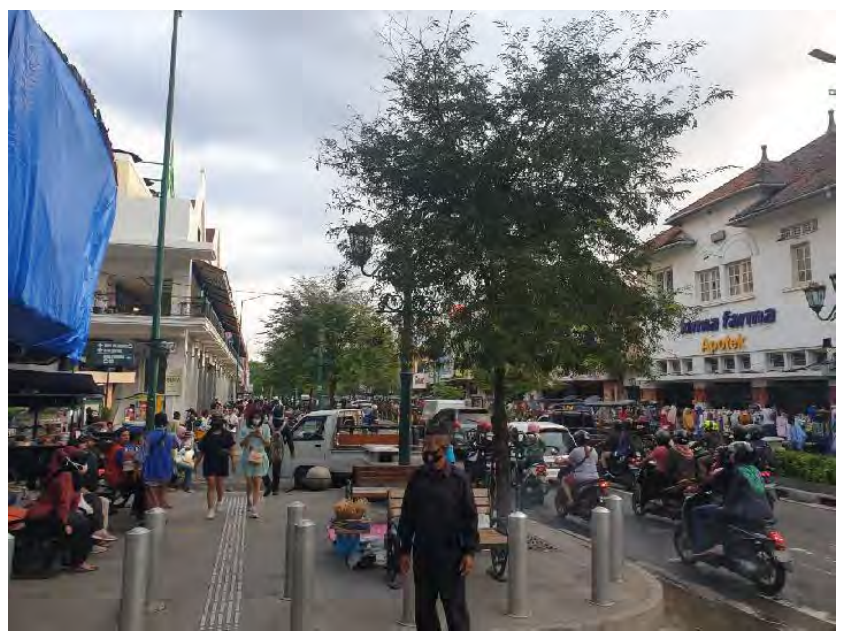

\section{Gambar 14. Jalan Malioboro ketika sore hari (titik amatan area 2)}

Pada Gambar 15 (Area 2) menunjukkan bahwa pejalan kaki dapat dengan mudah melupakan aturan physical distancing bergantung dari pengaturan konfigurasi ruang yang ada dan jumlah orang yang ada pada suatu ruang publik (Cristani, et al., 2020), meskipun pemerintah telah memberikan tanda pengingat atau signage tentang pengaturan arah berjalan. Hal tersebut, menunjukkan bahwa perlunya pengaturan street furniture yang lebih mendukung privasi, kluster terpisah, dan memberikan jarak aman dalam berinteraksi di Jalan Malioboro. 


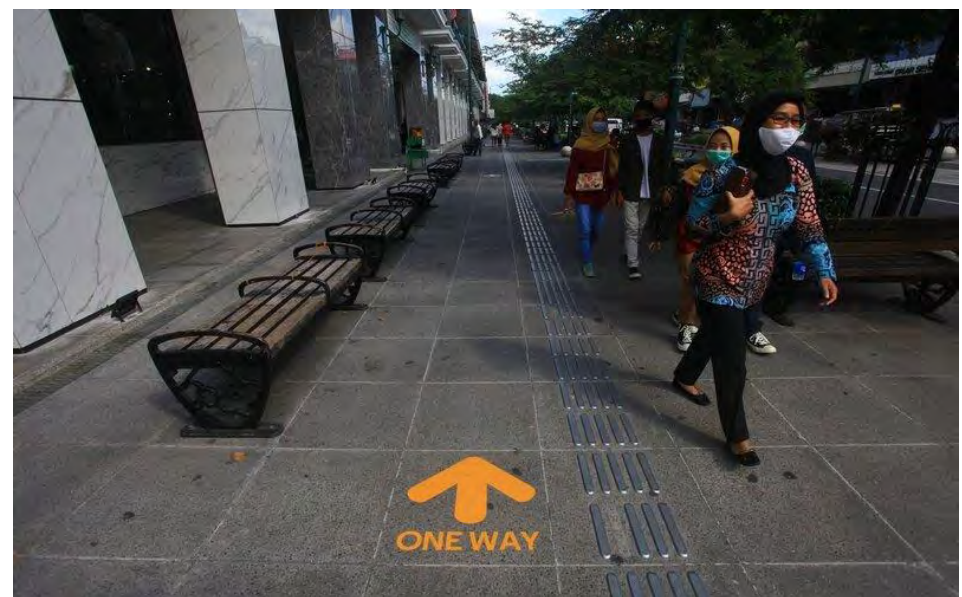

\section{Gambar 15. Signage satu arah jalur pedestrian di depan Malioboro Mall}

Arus pergerakan yang memicu kepadatan masa banyak ditemukan pada bagian frontage zone dan pedestrian through zone seperti yang diperlihatkan pada Gambar 16 yang merupakan hasil dokumentasi pada titik amatan area 13. Frontage zone merupakan ruang interaksi antara pengguna jalur pedestrian dengan fungsi bangunan, sedangkan pedestrian through zone merupakan zona yang dimanfaatkan sebagai lalu lalang bagi pejalan kaki (Hendrawan \& Dwisusanto, 2018; NACTO, 2013),. Kaitannya dengan penerapan aturan physical distancing, area inilah yang seharusnya menjadi prioritas penataan.

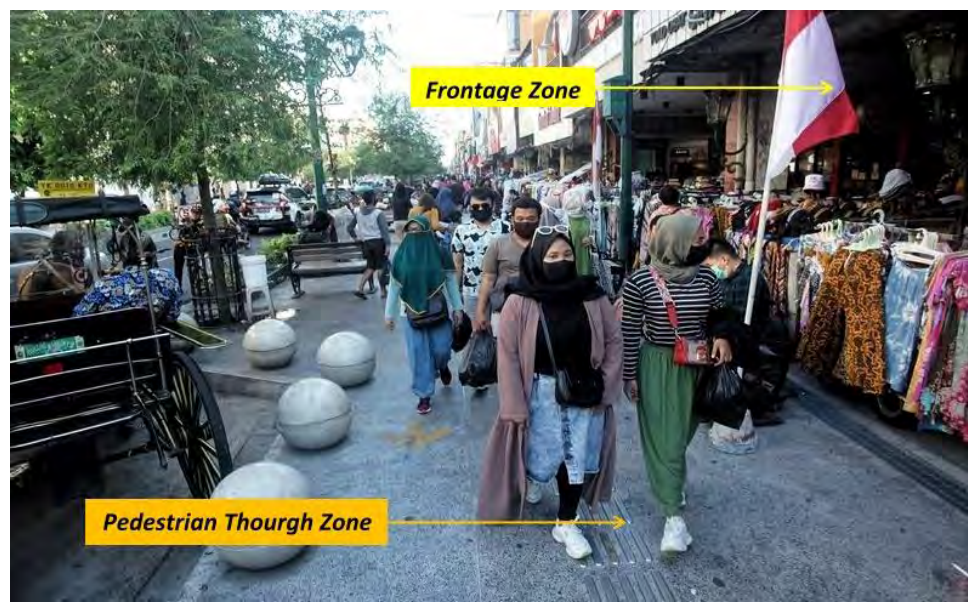

Gambar 16. Zona pejalan kaki di Jalan Malioboro (area 13)

Frontage zone seharusnya ditata dengan baik dengan cara memisahkan pejalan kaki yang bergerak masuk ke dalam fungsi bangunan dengan pedagang yang berjualan di depan bangunan. Sebaiknya, terdapat akses langsung dari frontage zone menuju fungsi bangunan yang memberi kontinuitas gerak dari jalur pedestrian ke dalam bangunan namun tetap memperhatikan kebijakan physical distancing. Kapasitas frontage zone terkait implementasi physical distancing dapat ditunjukan pada Gambar 17, bahwa apabila terjadi peningkatan kepadatan masa maka akan semakin sulit menjalankan aturan tersebut. Pada area pedestrian through zone pejalan kaki diberi kebebasan untuk berjalan tanpa interupsi, berarti dari kendaraan bermotor sekaligus melakukan implementasi physical distancing. 


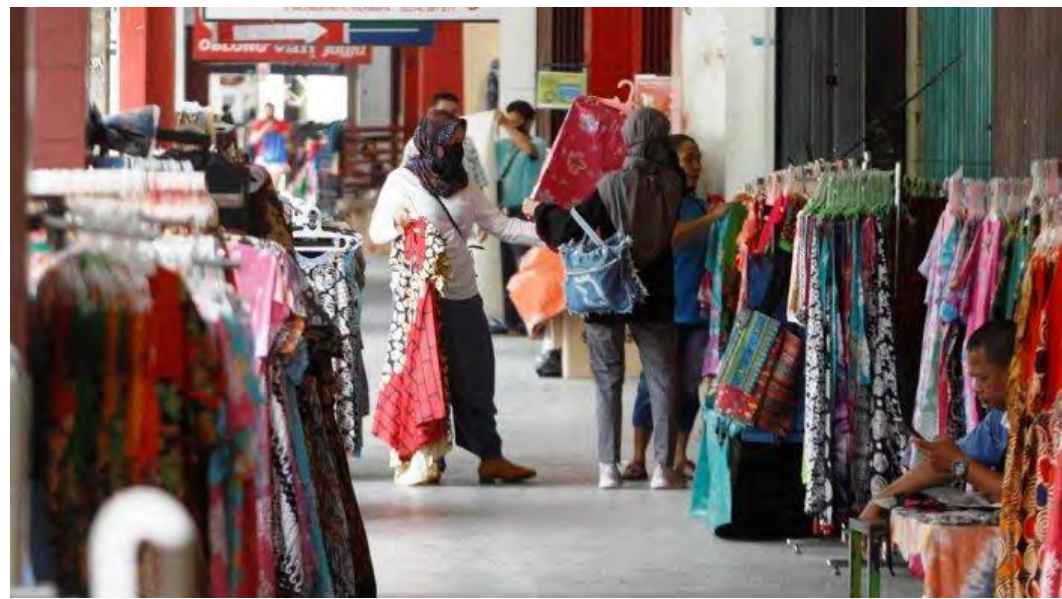

\section{Gambar 17. Zona depan bangunan (frontage zone) pejalan kaki Jalan Malioboro Sumber: (jogja.tribunnews.com, 2021)}

Menurut Tim Stonor (2020), founder dari Space Syntax Laboratory, menyebutkan bahwa aturan physical distancing akan dapat diterapkan dengan baik apabila sebuah infrastruktur kota dapat memahami bagaimana hubungan antara aspek permintaan (demand) dan aspek penyediaan (supply) (Stonor, 2020). Dalam hal ini, kapasitas yang dimiliki Malioboro dianggap sebagai pedestrian supply, yakni penataan spasial kawasan yang dimiliki Malioboro lebih rendah dari pada pedestrian demand. Yang dimaksud sebagai pedestrian demand adalah kebutuhan pejalan kaki untuk berpindah atau bergerak. Sehingga, dapat dikatakan bahwa kebutuhan akan ruang untuk pedestrian meningkat pada saat pandemi ini.

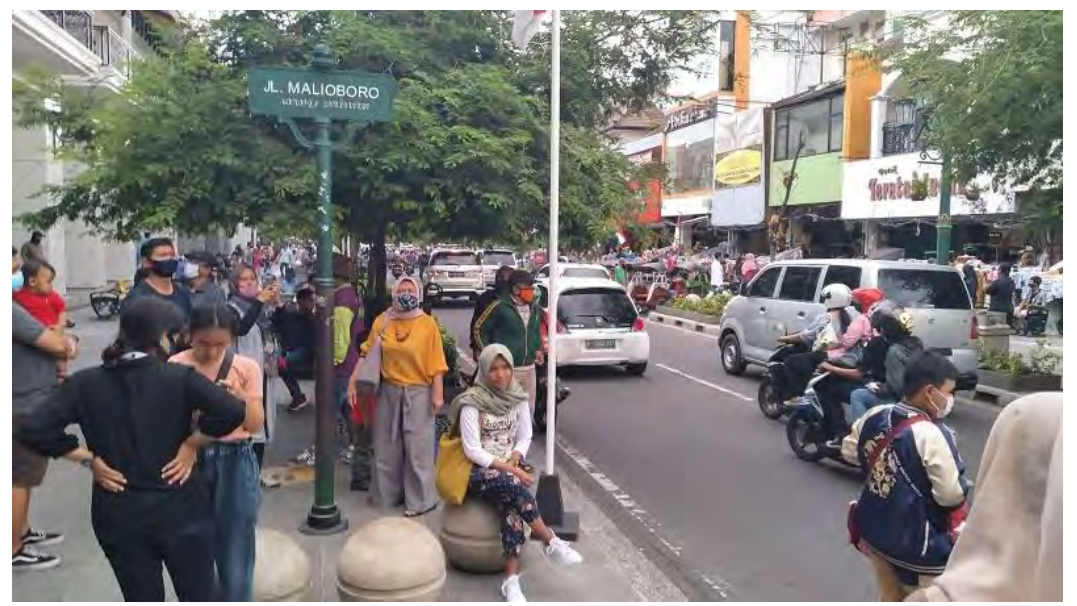

Gambar 18. Kepadatan pada titik amatan area 2 Jalan Malioboro

Berdasarkan keadaan yang terjadi di atas, dapat disimpulkan bahwa Jalan Malioboro yang dominannya merupakan jalan komersial diperlukan untuk mengatur ulang penggunaan ruangnya. Hal tersebut dapat dilakukan dengan menyeimbangkan penggunaan ruang jalan untuk pedestrian dan kendaraan guna memberikan ruang yang lebih bagi pejalan kaki. Konsep tersebut sesuai dengan teori Stephen C. Daves dalam bukunya Designing Effective Pedestrian Improvements in Business Districts (1982), yang menyebutkan bahwa dengan mendesain atau merubah fisik pada jalan (seperti pelebaran trotoar atau membatasi pergerakan dengan elemenelemen street furniture) dan dengan mengubah peraturan dalam mengontrol fungsi jalan dapat memenuhi kebutuhan ruang yang lebih bagi pejalan kaki untuk memaksimalkan physical distancing (Davies, 1982).

Menurut Alex Clewett, dalam panduan Covid-19 and the Future of Transport (2020), menyebutkan bahwa apabila terjadi peningkatan kebutuhan pejalan kaki (pedestrian demand), 
solusi yang dapat diterapkan dengan baik adalah menerapkan skema filtered permeability (permeabilitas yang disaring), yakni dengan membatasi kendaraan dan memprioritaskan berjalan kaki dan bersepeda. Struktur jalan yang memiliki permeabilitas yang baik seharusnya mampu mendorong orang untuk mengurangi penggunaan kendaraan dengan membuat perjalanan lokal menjadi lebih mudah dan menyenangkan untuk pejalan kaki (Mott MacDonald, 2020). Contoh skema yang dapat dilakukan dengan menerapkan kebijakan yang berbeda selama hari, misalnya pada waktu jam 12 hingga jam 2 siang, akses jalan diperuntukkan bagi pejalan kaki dan akses kendaraan penuh diizinkan sepanjang hari.

Konsep filtered permeability sesuai dengan solusi perencanaan ruang jalan yang dipaparkan oleh (Lewis, et al., 2020) dalam studi analisis yang berjudul Manual of Physical Distancing, yang menyebutkan bahwa ide jalan bebas kendaraan atau open street merupakan salah satu solusi efektif dalam memaksimalkan penerapan physical distancing pada jalan yang bermobilitas tinggi. Hal tersebut juga dibuktikan dengan studi kasus pada salah satu jalan di New York, yaitu 82th Street, Jackson Height. Namun, pendekatan skema filtered permeability membutuhkan pengelolaan atau manajemen aktif dari hari ke hari untuk memastikan keberhasilannya. Beberapa kota juga menerapkan kebijakan perubahan jalur kendaraan menjadi jalan ramah pejalan kaki. Selain karena terjangkau, aktivitas jalan kaki dapat mendorong gaya hidup sehat, memacu manfaat ekonomi daerah, dan menjadi bagian tak terpisahkan dari akses masyarakat terhadap transportasi umum (Peters, 2016).

Milan, sebagai kota paling tercemar di Eropa, telah merencanakan secara permanen untuk mengubah jalan sepanjang tiga puluh lima kilometer menjadi jalur sepeda dan pejalan kaki sebagai bagian dari upaya untuk memulihkan ekonominya dan mendorong perdagangan selama musim panas (Broom, 2020; Welle \& Avelleda, 2020). Menyikapi kondisi tersebut, pelebaran ruang jalan bagi pedestrian atau pejalan kaki menjadi sangat penting dalam memaksimalkan implementasi aturan physical distancing. Penataan ulang fungsi jalur pejalan kaki harus memperhatikan kebutuhan pengguna dan protokol kesehatan terkait aturan physical distancing selama pandemi.

\section{SIMPULAN DAN SARAN}

Berdasarkan analisis dan pembahasan terhadap temuan penelitian dapat disimpulkan bahwa permeabilitas kawasan Malioboro relatif tinggi yang berarti kualitas konfigurasi ruang Jalan Malioboro mudah diakses bagi pejalan yang bergerak menggunakan kaki ataupun kendaraan. Ruang jalan yang memiliki aksesibilitas tinggi akan memicu kepadatan yang tinggi, terutama pada Jalan Malioboro hingga Jalan Margo Mulyo. Peningkatan pergerakan pejalan kaki tetinggi terjadi di sekitar area Malioboro Mall pada malam hari. Namun, terjadinya peningkatan jumlah pejalan kaki tidak disertai dengan pangaturan sirkulasi. Pada penelitian menunjukkan bahwa terdapat korelasi antara kualitas konfigurasi ruang dan pergerakan pejalan kaki yang berakibat pada peningkatan kepadatan masa dari pagi ke malam hari. Hal tersebut banyak menimbulkam crossing atau persinggungan antar kepadatan pejalan kaki dan kendaraan yang menghambat implementasi physical distancing.

Jalur pejalan kaki yang menjadi prioritas penataan adalah frontage zone dan pedestrian through zone dikarenakan kapasitas infrasturktur kedua zona tersebut terhadap implementasi physical distancing menjadi tidak efektif apabila terjadi peningkatan kepadatan masa. Sehingga, dapat dikatakan bahwa terdapat peningkatan terhadap kebutuhan akan ruang untuk pedestrian atau pejalan kaki pada saat pandemi COVID-19 di Jalan Malioboro. Hal tersebut menyebabkan perlunya mendesain atau merubah fisik pada jalan (seperti pelebaran trotoar atau redesain street furniture) dan mengubah peraturan dalam mengontrol fungsi jalan (skema jalan bebas kendaraan) dalam memenuhi kebutuhan peningkatan pedestrian masa pandemi.

Menilik dari kesimpulan yang ada, rekomendasi program yang dapat berikan supaya aturan physical distancing tidak terhambat penerapannya bahkan saat mengalami peningkatan 
kepadatan di Jalan Malioboro, yaitu melalui strategi dalam mengelola fungsi jalan. Strategi ini berfokus pada kebutuhan akan ruang jalan yang lebih untuk physical distancing di Jalan Malioboro. Seringkali terdapat cukup ruang untuk physical distancing di jalan, tetapi sebagian besar digunakan untuk kendaraan. Ruang jalan untuk mobilitas yang aman dan physical distancing dapat diperoleh melalui berbagai pengelolaan fungsi ruang jalan, seperti:

a. Menghapus tempat parkir individu atau parkir tepi jalan,

b. Menggeser tempat parkir atau bongkar muat kendaraan menjauh dari tepi jalan utama,

c. Mempersempit jalur kendaraan bermotor dan memperlebar jalur pejalan kaki,

d. Menetapkan Jalan Malioboro sebagai jalan yang hanya diakses oleh transportasi umum guna mengurangi volume dan kecepatan kendaraan, sampai dimana ruang jalan dapat digunakan bersama,

e. Menutup jalur kendaraan bermotor (road closure), atau penerapan skema open street, guna memungkinkan physical distancing yang memadai untuk meningkatkan aksesibilitas dan keselamatan pejalan kaki,

f. Menata kios pedagang yang berada di depan bangunan sepajangan Jalan Malioboro supaya lebih dapat memperoleh space untuk melakukan pyhsical distacning. Dapat dengan memanfaatkan ruang jalan sebagai kegiatan komersil saat road closure atau merelokasi pedangan ketempat lain,

g. Mengelola arus pejalan kaki dengan fokus pada bagian depan gedung, pada titik-titik konflik seperti persimpangan atau zona jalan dengan street furniture untuk membantu mengelola arus pejalan kaki,

h. Memaksimalkan sikulasi akses titik masuk dan keluar bangunan satu arah (one-way entry and exit point) dengan tetap memperhatikan kebutuhan penyandang disabilitas, lansia, dan pertimbangan keamanan,

Namun, perlu diingat bahwa rekomendasi solusi yang telah diuraikan di atas atau kebijakan-kebijakan yang nantinya diterapkan di Jalan Malioboro perlu melibatkan pemangku kepentingan lokal seperti kelompok masyarakat, penyedia layanan sosial, asosiasi bisnis, dan toko serta pekerja. Pemantauan pelaksanaan kebijakan pun juga perlu dilakukan setiap hari guna memastikan keberhasilannya sehingga dapat meningkatkan kebijakan tersebut ke depannya lebih baik lagi.

Selain itu, perlunya studi lanjutan untuk memperkuat hasil temuan penelitian ini. Salah satunya dengan melakukan studi simulasi pergerakan pejalan kaki dengan implementasi physical distancing di Jalan Malioboro melaui software yang dikembangkan oleh developer, misalnya program Pedestrian Simulation Modeling yang dikembangkan oleh (Coffman Engineers, 2020), program Pedestrian Dynamics oleh (INCONTROL, 2020), atau program MassMotion milik (ARUP, 2020). Sedangakan, rekomendasi untuk pelaksanaan studi dalam mengamati pergerakan pejalan kaki alangkah lebih baik bila observasi dilaksanakan selama lebih dari seminggu. Durasi waktu observasi yang lama diperlukan karena kehidupan di ruang publik bisa berubah-ubah tergantung faktor-faktor yang mempengaruhinya (Westlund, 2018). Perlunya penambahan teknik observasi dengan metode mapping (pemetaan) untuk memahami lebih detail tentang lokasi dan ragam aktivitas yang terjadi di ruang publik (Gehl \& Svarre, 2013), dibanding metode tracing dan tracking yang digunakan dalam penelitian ini.

\section{DAFTAR RUJUKAN}

Abdul Nasir, N. A. B., Hassan, A. S., Khozaei, F. \& Abdul Nasir, M. H. B., 2020. Investigation of spatial configuration management on social distancing of recreational clubhouse for COVID-19 in Penang, Malaysia. International Journal of Building Pathology and Adaptation. 
Alter, L., 2020. Urban Design After the Coronavirus. [Online] Available at: https://www.treehugger.com/urban-design-after-coronavirus-4848013 [Diakses 12 November 2020].

Andi, Zain, Z. \& Andi, U. F., 2020. Studi Konfigurasi Ruang Mall (Studi Kasus: Matahari Mall dan Ayani Megamall di Pontianak). ARSITEKTURA: Jurnal Ilmiah dan Arsitektur Lingkungan Binaan, 18(2), pp. 265-276.

Anugrahanto, N. C., 2020. Seorang PKL Malioboro Positif Covid-19. [Online] Available at: https://www.kompas.id/baca/nusantara/2020/09/06/seorang-pkl-malioboro-positifcovid-19/ [Diakses 24 Oktober 2020].

Aqli, W., 2019. Konfigurasi Jalur Pedestrian yang Permeable di dalam Area Barier antara Kawasan Bangkitan dan Tarikan. Jurnal SCALE, 6(1), pp. 14-23.

ARUP, 2020. Powerful pedestrian simulation software from Arup. [Online] Available at: https://www.arup.com/expertise/services/digital/massmotion [Diakses 21 Januari 2021].

Broom, D., 2020. How the COVID-19 crisis inspired this Italian city. [Online] Available at: https://www.weforum.org/agenda/2020/04/milan-covid-19-coronavirus-lockdownreducing-car-use/ [Diakses 19 Januari 2021].

Carmona, M., 2019. Principles for public space design, planning to do better. URBAN DESIGN International, Volume 24, pp. 27-59.

Chu, D. K. et al., 2020. Physical distancing, face masks, and eye protection to prevent personto-person transmission of SARS-CoV-2 and COVID-19: a systematic review and metaanalysis. Lancet, Volume 395, pp. 1973-1987.

Coffman Engineers, 2020. Adapting to the New Norm. [Online] Available at: https://www.coffman.com/pedestrian-simulation-modeling-for-covid-19/ [Diakses 23 Januari 2021].

covid19.go.id, 2020. Apa dan Bagaimana Cara Physical Distancing?. [Online] Available at: https://covid19.go.id/tanya-jawab?search [Diakses 1 Oktober 2020].

Cristani, M. et al., 2020. The Visual Social Distancing Problem. IEEE Access, Volume 8, pp. $126876-126886$.

Davies, S. C., 1982. Designing Effective Pedestrian Improvements in Business Districts. 3th penyunt. Chicago: American Planning Association.

Ducharme, J., 2020. World Health Organization Declares COVID-19 a 'Pandemic'. [Online] Available at: https://time.com/5791661/who-coronavirus-pandemic-declaration/ [Diakses 14 Januari 2021].

Ephes, L. M., 2006. The Architecture of Permeability-Urban Redevelopment of Fa Yuen Street, Hong Kong: University of Hong Kong.

Florida, R., 2020. We'll Need To Reopen Our Cities. [Online] Available at: https://www.bloomberg.com/news/articles/2020-03-27/how-to-adapt-cities-to-reopenamid-coronavirus [Diakses 23 Oktober 2020].

Gehl, J. \& Svarre, B., 2013. How to Study Public Life. Washington: Island Press.

Gupta, R. \& Dhamija, R. K., 2020. Covid-19: Social distancing or social isolation?. BMJ , Volume 369, p. m2399.

Hendrawan, C. \& Dwisusanto, Y., 2018. Konsep Acting Living dalam Perancangan Jalur Pedestrian Studi Kasus: Jalan L. L. R. E. Martadinata (Riau), Bandung, Jawa Barat. ARTEKS, Jurnal Teknik Arsitektur, Volume 2, pp. 15-31.

Hillier, B. \& Hanson, J., 1984. The Social Logic of Space. London: Cambridge University Press.

Honey-Rosés, J. et al., 2020. The Impact of COVID-19 on Public Space: A Review of the Emerging Questions. 
INCONTROL, 2020. Physical Distancing in Pedestrian Dynamics. [Online] Available at: https://www.incontrolsim.com/physical-distancing-in-pedestrian-dynamics/ [Diakses 21 Januari 2021].

jogja.tribunnews.com, 2021. Buka Kios Setelah Libur Lebaran, PKL Malioboro: Tak Ada Perubahan. [Online] Available at: https://jogja.tribunnews.com/2020/05/27/buka-kiossetelah-libur-lebaran-pkl-malioboro-tak-ada-perubahan [Diakses 14 Januari 2021].

Lewis, P., Lewis, D. J., Tsurumaki, M. \& Nordenson, G., 2020. Manual of Physical Distancing - Space, Time, and Cities in the Era of COVID-19, Princeton: Princeton University Funding for Rapid, Novel and Actionable Covid-19 Research Projects.

Litscher, M., 2020. Sidewalks in the city during and after COVID-19. [Online] Available at: https://thinking-cities.h3bconnected.com/t-cities-july-2020/switzerland-environmenthealth-in-transport/ [Diakses 23 Oktober 2020].

Mahadi, K. I. \& Budiarti, F., 2016. Strategi Penataan Kawasan Malioboro menjadi Kawasan Pedestrian. Jurnal Planes (Planologi), 7(2), pp. 51-59.

Marlina, P., 2020. Analisa Desain Jalur Pedestrian dengan Konsep Walkability, Medan: Universitas Sumatra Utara.

Mauliani, L., Purwantiasning, A. W. \& Aqli, W., 2013. Kajian Jalur Pedestrian sebagai Ruang Terbuka pada Area Kampus. Jurnal Arsitektur NALARs, Volume 12.

Mensana, A., Srinaga, F. \& Halim, A., 2019. Generating Social Interaction through Improving Quality of Connection Spaces between City Parks. Jurnal Strategi Desain \& Inovasi Sosial, 1(1), pp. 96-113.

Mott MacDonald, 2020. Covid-19 and the future of transport, Croydon: The Mott MacDonald Group.

NACTO, 2013. Urban Street Design Guide. New York: Island Press.

NACTO, 2020. Streets for Pandemic Response and Recovery. [Online] Available at: https://nacto.org/wpcontent/uploads/2020/09/Streets_for_Pandemic_Response_Recovery_Full_20-0924.pdf [Diakses 21 Desmber 2020].

Naro, A. \& Hendola, F., 2020. Analisis Pengaruh Desain Menteng Park Bintaro Jaya Terhadap Interaksi Sosial. Jurnal Strategi Desain dan Inovasi Sosial, 1(2), pp. 200-215.

Nazmy, E., 2020. The Effect of Social Distancing on the Utilization of Open Spaces Case Study: "Open Social Spaces at Smash Academy Club"(Dept.A). Mansoura Engineering Journal, 45(4), pp. 69-77.

Null, S. \& Smith, H., 2020. COVID-19 Could Affect Cities for Years. [Online] Available at: https://thecityfix.com/blog/covid-19-affect-cities-years-4-ways-theyre-coping-nowschuyler-null-hillary-smith/ [Diakses 15 Oktober 2020].

Oberklaid, S., 2015. Observing People in Pike Place, Part 1. [Online] Available at: https://www.theurbanist.org/2015/10/12/observing-people-in-pike-place-part-1/ [Diakses 10 Januari 2021].

Peters, A., 2016. 50 Reasons Why Everyone Should Want More Walkable Streets. [Online] Available at: https://www.fastcompany.com/3062989/50-reasons-why-everyoneshould-want-more-walkable-streets [Diakses 16 Januari 2021].

Psyllidis, A. et al., 2020. Social Distancing and The City. [Online] Available at: https://socialglass.tudelft.nl/social-distancing/ [Diakses 3 Januari 2021].

Rubenstein, H. M., 1978. Central City Malls. New York: Wiley.

Schwartz, K., 2020. Relationship Between Physical Distancing and Space Planning. [Online] Available at: https://spaceiq.com/blog/physical-distancing-and-space-planning/ [Diakses 12 September 2020]. 
Shiue, I., 2016. Future urban design strategies for health and wellbeing: proposal of DIDID action plan and design mapping. Journal of Engineering, Design and Technology, 14(1), pp. 104-114.

Siregar, J. P., 2014. Metodologi dasar space syntax dalam analisis konfigurasi ruang. Malang: Universitas Brawijaya.

Stonor, T., 2020. Is physical distancing possible on city streets?. [Online] Available at: https://timstonor.wordpress.com/2020/04/28/is-physical-distancing-possible-on-citystreets/ [Diakses 5 Januari 2021].

UN-Habitat, 2020. UN-Habitat Guidance on COVID-19 and Public Space. [Online] Available at: https://unhabitat.org/sites/default/files/2020/06/un-habitat_guidance on covid19 and public space.pdf [Diakses 1 Desember 2020].

Vujadinovic, M., 2016. A typological classification of neighbourhood public open spaces: A case study of Novi Grad - Podgorica. Facta universitatis - series: Architecture and Civil Engineering, 14(1), pp. 111-121.

Welle, B. \& Avelleda, S., 2020. Safer, More Sustainable Transport in a Post-COVID-19 World. [Online] Available at: https://www.wri.org/insights/safer-more-sustainabletransport-post-covid-19-world [Diakses 19 Januari 2021].

Westlund, K., 2018. Methods for Studying Public Spaces' Impact on Their Life, Sweden: Luleå University of Technology.

WHO, 2020. Physical distancing is not social isolation. [Online] Available at: https://www.who.int/indonesia/news/novel-coronavirus/new-infographics/physicaldistancing-not-social-isolation [Diakses 1 Desember 2020].

Wilder-Smith, A. \& Freedman, D. O., 2020. Isolation, quarantine, social distancing and community containment: pivotal role for old-style public health measures in the novel coronavirus (2019-nCoV) outbreak. J Travel Med, 27(2), pp. 1-4. 